that many courts will reach the conclusion that the housing emergency is over, at least in the predictable future, ${ }^{30}$ simply because federal rent control may go by the board. "3x "A law depending upon the existence of an emergency or other certain state of facts to uphold it may cease to operate if the emergency ceases or the facts change even though valid when passed." 32 But the housing shortage has been in existence for a long time, and the prospects are that it will continue for many years to come. Nor is there reason to believe that the emergency which justifies congressional exercise of war powers will cease in the immediate future. ${ }^{33}$ In absence of state legislative action, it appears that the only way to fit tenancy law to national needs is through judicial action compatible with emergency rent legislation. Whether these decisions "suspending" common-law tenancy rules will have the weight of precedent after federal rent control ceases remains to be seen. As long as there is a housing shortage, it seems that they should.

\title{
PRICE DISCRIMINATION IN GASOLINE MARKETING: THE DETROIT JOBBERS CASE
}

Standard Oil Co. v. Federal Trade Commission, ${ }^{\mathrm{x}}$ with a long history and a flood of comment to its credit, recently gave the Supreme Court an opportunity to settle an important question of construction under Section 2 (b) of the Robinson-Patman Act. ${ }^{2}$ However, the case also presented interesting economic questions concerning price discrimination in gasoline marketing, questions which received little attention in the Court's opinions and which have not been treated fully elsewhere. This comment essays a fresh appraisal by way of a factual analysis of the market in question and a theoretical observation on price dis-

${ }^{30}$ See Peck v. Fink, 2 F. 2d 9 I2 (App. D.C., I924). The court relied upon a statement by Justice Holmes in Chastleton Corp. v. Sinclair, 264 U.S. 543, 549 (r924) that "if the question were only whether the statute is in force today, upon the facts that we judicially know we should be compelled to say that the law has ceased to operate," to hold that the rent act for the District of Columbia, 43 Stat. I20 (I924), was unconstitutional. See also Kahn v. Wall, 68 A. 2 d 862 (App. D.C., I949).

${ }^{3 x}$ The court in Li-Mo Realty Corp. v. Davis, I67 N.Y. Misc. 829,4 N.Y.S. $2 d 858$ (N.Y. Munic. Ct., 1938) relied upon the Report of the New York City Housing Authority, Jan. 25, 1937, and the City of New York Vacancy and Rent Survey as of January 1938 to satisfy itself that there was a housing shortage. Other courts could use similar means even though rent control had ceased.

${ }^{32}$ Chastleton Corp. v. Sinclair, 264 U.S. 543, 547 (I924), opinion of Justice Holmes who also stated that "[i]f about all that remains of war conditions is the increased cost of living, that is not in itself a justification of the act." Ibid., at 548 .

${ }^{33}$ While the present federal rent acts are based upon the war power of Congress, there are those who believe that other bases exist upon which the control of rents could be justified. See Landlord and Tenant after OPA, I4 Univ. Chi. L. Rev. 243 (I947) (housing affected with a public interest) and McCarthy, Aspects of Federal Rent Control, 3 I Corn. L.Q. 68 (I945) (use of monetary clause of the Constitution to invoke rent controls).

I 340 U.S. 23 I (I95I).

${ }^{2} 49$ Stat. $1_{526}$ (1936), $x_{5}$ U.S.C.A. $\$ I_{3}$ (I95I). 
crimination, both viewed in relation to some of the legal problems raised by Section 2(b) of the statute.

\section{I}

Standard of Indiana sold its "regular" branded gasoline in the Detroit market both to dealers and to jobbers. Some $35^{8}$ dealers, selling at retail, paid a posted tank wagon price. Four jobbers received the tank car price which was $x \frac{1}{2} \xi$ a gallon under the tank wagon price. Eligibility for the lower tank car price was based on credit standing, purchase of adequate gallonage and maintenance of bulk plant facilities. One of the four jobbers, Ned's, sold exclusively at retail and was a leading price cutter in the price wars which flourished in Detroit during the years in question (I936 to I940). ${ }^{3}$ The other three jobbers sold both at retail and at wholesale. In certain instances, one of them passed on part of the price differential by reselling to dealer customers at less than Standard's posted tank wagon price, as well as by retail price cutting.

Charging unlawful price discrimination under the Robinson-Patman Act, ${ }^{4}$ the Federal Trade Commission showed that Standard's price differential put dealers paying Standard's tank wagon price at a serious competitive disadvantage during the price wars. In order to maintain their gallonage, these dealers had to meet the lower prices of competing retailers who were benefiting directly or indirectly from the favorable tank car jobber price. Relying on Section 2 (b) of the statute, ${ }^{5}$ Standard sought to justify the discrimination, arguing that it would have lost the substantial jobber accounts to competing suppliers had it not granted them the tank car price. ${ }^{6}$ The Commission refused to consider evidence on the point, holding that as a matter of law this was no defense in the face of affirmative proof of injury to competition. A cease and desist order was issued $^{7}$ which was modified and affirmed by the Seventh Circuit Court of Appeals. ${ }^{8}$ With three judges dissenting, the Supreme Court reversed, holding that a seller who proves that his discriminatory lower price was granted in good

3 Ned's had also received a price concession of $\frac{1}{2} \phi$ a gallon while still nominally a dealer between 1936 and 1938 . In the latter year, it was recognized as a jobber.

449 Stat. $1_{526}$ (1936), ${ }_{5}$ U.S.C.A. \& $1_{3}$ (195I).

5 Quoted infra, p. 64 .

${ }^{6}$ The Commission and the courts rejected a jurisdictional argument that the purchases involved were in intrastate commerce. As to Standard's attempt to show cost justification under $\S 2(a)$, abandoned before the reviewing courts, see note 69 infra.

7 Findings of fact and original order, Standard Oil Co., 4r F.T.C. 263 (I945); modified order, 43 F.T.C. 56 (1946). Commissioner Mason dissented on the following grounds: 1 ) The modified order was too indefinite to be followed, 2) The \$2(b) proviso set out an absolute defense as to which the Commission should have made a finding, 3) The Commission failed to find explicitly, as required by the statute, that the purchases involved were in interstate commerce and 4) There was no proof of injury to competition. 43 F.T.C. 56,59 (1946). As to the last, see note 72 infra.

${ }^{8}$ Standard Oil Co. v. Federal Trade Commission, I 73 F. 2 d 2 ro (C.A. 7 th, I949). Consult notes, 59 Yale L.J. I58 (1949); 62 Harv. L. Rev. I249 (1949); 49 Col. I. Rev. 863 (1949); (1949) U. of Ill. L. Forum 54I. The case has produced a flood of lucubration threatening to dwarf the record in size. For additional citations, see notes $9,56,65,68$ infra. 
faith to meet an equally low price of a competitor has an absolute defense under the Robinson-Patman Act.9 The Court remanded the case to the FTC which must now determine whether Standard has sustained the burden of proving the defense.

II

Justice Burton, speaking for the majority, had little to say about the characteristics of the Detroit gasoline market. The economic significance of the price wars and the alleged injury to competition received only passing comment. The background of the case indicates, however, that these matters merit closer attention.

The Robinson-Patman Act theory is that price discrimination injures competition. This fact and the frequent charges of monopoly levelled at the oil industry pose the question whether the price discrimination in the present case served to encourage or discourage competition in the Detroit market.

As to the oil industry generally, it is said that the vertically integrated major oil companies utilize their position to freeze out any serious independent competition and refrain from competing with each other..$^{10}$ More specifically relevant are two of the allegations in the Mother Hubbard case, a complaint brought in I 940 against twenty-two major oil companies. It was charged that by withdrawing nominally from the operation of retail outlets, major companies place the burden of retail competition on the service station operator who is forced to subsist on inadequate profit margins. ${ }^{x x}$ Further, the major companies were said to make frequent use of bogus independents [jobbers?] to discipline price-cutting independent competitors. ${ }^{\mathrm{Iz}}$

Indeed, some circumstances suggest that a "monopoly" hypothesis might be a fruitful one in the present case. Standard of Indiana, one of the defendants in the Petroleum Institute complaint, was in 1938 the third largest major oil com-

9 Standard Oil Co. v. Federal Trade Commission, 340 U.S. 23I (I95I). First comment: 36 Iowa L. Rev. $35^{I}$ ( $195 \mathrm{I}$ ). The case was first argued before the Court in January I950 but was restored to the docket for reargument. 339 U.S. 975 ( $\left(95^{\circ}\right)$. At the time of the first argument, Sen. $x 008$ was pending in Congress. In its final form, Section 3 of the bill provided that "a seller may justify a discrimination by showing that his lower price . . . was made in good faith to meet an equally low price of a competitor." Sen. Doc. 184, 8Ist Cong. $2 \mathrm{~d}$ Sess. (I950). President Truman vetoed the measure. 96 Cong. Rec. 8,844 (June I6, I950). For a critical view of the legislative history, see Latham, The Politics of Basing Point Legislation, ${ }_{5}$ Law \& Contemp. Prob. 272 (r950). Contra: Simon, Geographic Pricing Practices, IIg-80 (r950).

Shortly after the Supreme Court decision, bills were introduced in both houses of Congress intended to establish beyond doubt that the holding in the Standard case is law. Sen. 719, 82d Cong. Ist Sess. (195I); H.R. 2820, 82d Cong. xst Sess. (I95I).

ro The literature is vast. Rostow, A National Policy for the Oil Industry (r948) is one of the best.

II Complaint, If 66, United States v. American Petroleum Institute, Civil Action No. 8524 (D.C.D.C., I940). Compare Black, Exclusive Dealer Devices in the Marketing of Petroleum Products, 29 Geo. L.J. 439, 449 et seq. (I94I).

${ }^{22}$ Complaint, 954 , United States v. American Petroleum Institute, Civil Action No. 8524 (D.C.D.C., I940); Prayer for Relief, 19 . 
pany in the United States, marketing petroleum products in ${ }^{4} 4$ states. ${ }^{x 3}$ It was also the largest marketer in Detroit between 1936 and 1940 , with $16 \%$ to $17 \%$ of the sales made there, ${ }^{24}$ Together, nine to twelve major companies sold $87 \%$ of the gasoline consumed in Detroit. ${ }^{55}$ These major suppliers normally sold at a uniform, publicly posted tank wagon price to their dealers. ${ }^{.6}$ Standard appears to have been the price leader. ${ }^{x 7}$ In only one instance did a major supplier other than Standard initiate a cut in tank wagon prices; ${ }^{28}$ and Ned's was but one of five major-supplied jobbers cutting retail prices. ${ }^{19}$ Complaints charging discrimination similar to that practiced by Standard were also filed against three other major suppliers, with hearings postponed pending the outcome of this case. $^{20}$

Among these circumstances, one fact does stand out as evidence of noncompetitive practices among major suppliers. In a competitive market, discrimination practiced by one of many sellers would not last since competing sellers would offer lower prices to the customers being discriminated against. Since here a group of sellers were discriminating in like fashion, it might be concluded that at least the members of this group were not behaving competitively.

The FTC and the Circuit Court were satisfied with an "injury to competition" explanation of Standard's price discrimination. The Supreme Court and many commentators were content with an analysis of the discrimination as a defensive tactic used by a seller to protect established customer accounts against a price raid by competing suppliers. A closer look at the facts suggests a more satisfactory hypothesis than either of these.

Independent marketers were making a determined effort to enlarge their share of Detroit gasoline sales. ${ }^{2 x}$ Non-major brand gasoline was normally sold

${ }^{2}$ I 4 A TNEC Hearings on Investigation of Concentration of Economic Power 7,708, 76th Cong. 2d Sess. (I939). A major oil company is usually characterized as completely integrated, i.e., as operating on all of the four functional levels in the industry: production, transportation, refining and marketing. Transcript of Record at 94I, I,900, Standard Oil Co.v. Federal Trade Commission, 340 U.S. 23I (r95I) (hereafter cited as Record).

14 Standard Oil Co., 4I F.T.C. 263, 27I (1945). Annual computations between 1936 and I940 show $1.2 \%$ as the largest variation in Standard's share of the market. Respondent's Exhibit No. 58 , Record at 4,879 .

xs Record at 335. Three suppliers were listed by the Trial Examiner as "doubtful" majors. Record at 5,106.

${ }^{16}$ Record at 126-3I.

17 Record at r26-3r. Compare Burns, The Decline of Competition 93-109 (r936).

${ }^{18}$ Record at 5,114.

19 Record at 5,II3.

${ }^{20}$ Gulf Refining Co., F.T.C. Docket No. 439o; Texas Co., F.T.C. Docket No. 439r; Shell Oil Co., F.T.C. Docket No. 4392.

${ }^{2 x}$ Standard's counsel in fact outdistanced the F.T.C. in condemning price-cutting competition. In his view, off-brand gasoline marketers were the real defendants in the action, since none of Standard's prices were as low as the retail prices on such gasoline. Record at r,4I2. 
at two cents a gallon less than major brands. But at times between 1936 and I940 the differential rose as high as six cents a gallon. ${ }^{22}$ Detroit independents seem not to have been in the usual "squeeze" said to stem from major control of pipeline facilities. Michigan wells then produced about $30 \%$ of the state's consumption ${ }^{23}$ and all but two of the twenty-six refineries in Michigan in 1938 were independents." Further, Detroit was known as a "dumping ground" for surplus gasoline in the Midwest. ${ }^{25}$ The extent of the surplus during these years is suggested by the fact that during I938 Michigan refineries were offering gasoline to dealers at three cents a gallon under prevailing tank wagon prices. ${ }^{26}$ When independent brands sold at more than a two-cent differential under major brands, major sales dropped and independent sales increased. ${ }^{27}$ The major suppliers thus faced the possibility of losing much of their market position during the pre-r940 Detroit gasoline price wars. The danger was set by the fact that their dealers wanted to avoid price competition. During these years the Retail Gasoline Dealers Association of Michigan mapped out a four point program which included pressing for state legislation prohibiting unfair practices in the marketing of petroleum products. Such a statute was enacted ${ }^{28}$ and served as the basis for several actions brought in the state courts against leading Detroit price cutters. $^{29}$ The Association also urged the FTC to proceed against suppliers who granted tank car prices such as those attacked in the instant case..$^{30}$

In this situation, the price discrimination seems to have served two purposes. The first was to force the dealers paying tank wagon prices to enter the retail price competition in order to protect Standard's share of the market against aggressive independent competitors. This was accomplished by giving the lower price to the jobber accounts. Such customers could then cut retail prices in selling directly to consumers and pass on part of the differential in reselling to their dealer customers, putting the latter in a position to meet price competition without seriously impairing their profit margins. The dealers who had attempted to freeze retail prices were now faced not only by independent gasoline selling at lower prices but also by dealers selling the same branded gaso-

22 Respondent's Exhibits Nos. 27, 28, Record at 4,829, 4,830.

${ }^{23}$ Record at 1,380 . Between 1936 and 1940 , Michigan refinery capacity more than doubled. Respondent's Exhibit No. 25-A, Record at 4,827.

24 Respondent's Exhibit No. 24, Record at 4,826.

25 Record at $1,900-903$.

${ }^{26}$ Record at $\mathrm{r}, 908$.

${ }_{27}$ Record at 327, I,386-88, 5,107, 5, I08; Respondent's Exhibit No. 28, Record at 4,830.

${ }_{28} 24$ Mich. Stats. Ann. (Henderson, I938) § 28.78 (Supp., I949).

${ }_{29}$ Record at 2,136-43; Commission's Exhibit No. 33-B, Record at 4,733. In People v. Victor, 287 Mich. 506, 283 N.W. 666 (1939), Section 6 of the statute, forbidding the use of premium gifts to promote the sale of gasoline, was held unconstitutional under the due process clause of the state constitution. See also People v. Austin, $3 \circ$ I Mich. 456, 3 N.W. 2d 84I (I942).

${ }^{30}$ Retail Gasoline Dealers Association of Michigan, Retail Gas Dealers News 3 (Aug., I940). 
line (Standard Red Crown) at two cents less than prevailing retail prices. The tank wagon dealers had to cut prices or lose their gallonage. ${ }^{3 x}$

The second aspect of the price discrimination is that it may have represented an attempt by Standard to break away from any understanding existing among the major suppliers not to compete with each other.

Standard's two largest major competitors in Detroit did not operate on a dual basis but sold only to dealers at tank wagon prices. ${ }^{32}$ The regional manager of one of these companies testified for the FTC at the hearing and took the position that outlawing the price discrimination would improve the competitive situation in Detroit's gasoline market.33 It is clear that the "improvement" was to consist of stabilized prices, at least as among the major companies. ${ }^{34}$ This same company initiated the I939 cut in tank wagon prices mentioned above. Arguably, this was retaliation for the effect which a major supplier had felt from Standard's discrimination and that of the other major suppliers against whom the FTC filed complaints. Significantly, some of the competitive offers which Standard's four jobber customers received were from other major suppliers in Detroit and several of these undercut Standard's tank car price. ${ }^{35}$ During I933 and I934, Standard had lost three jobber customers to other major suppliers who undercut Standard's tank car price. ${ }^{36}$ Such competition among major suppliers for jobber customers was in marked contrast to the lack of price competition in dealer tank wagon price postings. It lends weight to the hypothesis that any noncompetitive arrangement among the majors was honored partly in the breach. ${ }^{37}$

${ }^{3 x}$ An across-the-board cut in tank wagon prices would have been a more expensive way for Standard to meet the independent price competition. As to another possible reason why Standard preferred the method of channelling greater gallonage through the jobbers, see text infra.

The record does not disclose whether dealers caught in the price squeeze were forced out of business in any significant number. The attempted retail price fixing suggests that, as a general matter, a seller might seek a discriminatory price squeeze to lower retailer margins and increase sales. Cf. Kiefer-Stewart Co. v. Joseph E. Seagram \& Sons, 340 U.S. 2II (I95I). Here, however, the need to meet independent price competition was the important fact.

${ }^{32}$ Record at 320 (Sun Oil Co.) and 2, r30 (Socony-Vacuum).

33 Record at 345 .

34 "Q. In your opinion, what is the effect of this practice which I have just described [granting of preferential price by major suppliers to jobbers] . . . upon retail competition in the sale of major brand gasoline in Detroit?"

"A. My opinion is that it creates a very difficult competitive condition by reason of the fact that some marketers are able to buy at a lower cost than others, and it is the usual practice that the preferential buying leads to a lower retail price to either openly or through one means or another of discounting." Record at 320.

The same witness later spoke as follows of the attitude which his company sought to instill in its dealers. "We school them just diametrically opposite to creating a lower price competition. All of our efforts are bent on those two principles, not to create a low price competition, but when they are faced with it, to meet that competition." Record at 342 .

${ }_{35}$ Record at 5,099-104.

${ }^{36}$ Record at $x, 9$ r2 $-r 6$.

37 Counsel for the retailers, speaking in the Supreme Court as an amicus, had a different explanation of the price discrimination, according to which the major oil companies sought to 
Although the analysis of price discrimination as a tactic used by a seller in violating a monopolistic understanding is here advanced only as a hypothesis, it is of considerable general importance in view of the Robinson-Patman Act theory that price discrimination is a threat to competition. It has been argued that by forbidding price discrimination, the statute actually closes off what otherwise might be a spontaneously "subversive" force tending to undermine monopoly..$^{38}$

The belief that Standard's price discrimination thus encouraged competition both on retail and supplier levels may well have been behind the Justice Department's open disagreement with the FTC in the instant case. ${ }^{39}$ Publicly, the disagreement centered on the interpretation of Section $2(\mathrm{~b})$ of the Robinson-Patman Act, $4^{\circ}$ the question with which the Supreme Court's decision is largely concerned.

\section{III}

Standard sought to bring its price discrimination within the following proviso in Section $2(\mathrm{~b})$ :

That nothing herein contained shall prevent a seller rebutting the prima-facie case thus made by showing that his lower price or the furnishing of services or facilities to any purchaser or purchasers was made in good faith to meet an equally low price of a competitor, or the services or facilities furnished by a competitor. ${ }^{4 \mathrm{r}}$

avoid tank wagon price competition and used the jobbers as "dummies" to lower dealer profit margins. "A lowering of the dealer's margin increases the percentage of the price paid by the public which goes into the till of the major oil company. After such a margin reduction the tank wagon price can be raised without pushing the retail price above what the public was accustomed to paying previously. Unfair price competition between retailers is stimulated by giving an unearned advantage to a few, while tank wagon price competition between major oil companies remains practically non-existent." Brief for Retail Gasoline Dealers Association of Michigan, Amici Curiae at ${ }^{7} 7$, Standard Oil Co. v. Federal Trade Commission, 340 U.S. 23x (x95x).

But, ( $x$ ) in itself, an increase in the percentage of retail receipts which goes to the supplier will not increase his profits, although, if prices were lower, his sales may be increased. See point (3) infra and note 3 I supra. (2) The movement of tank wagon and retail prices portrayed on the previous page of this amicus' brief indicates that every rise in tank wagon price between $193^{6}$ and 1940 was followed by an increase in dealer margins, even assuming that all individual dealers were meeting the competition of sellers like Ned's. (3) Most important is the fact that the theory rests on the assumption that independent competition was not a serious problem for the major suppliers in Detroit. The assumption as stated (ibid., at 17 ) seems to be based solely on the fact that independent off-brand gasoline accounted for only thirteen per cent of Detroit gasoline sales. However, the Michigan independent marketers were in a position to offer stiff competition to the majors, as noted above. It seems probable that the independents would have had some success in trying to enlarge their share of the market had not the majors forced their dealers' prices down by "subsidizing" price-cutting jobbers.

Episode from the testimony of Standard's division manager concerning the prices of nonmajor gasolines:

"Q. You would be very glad if all the gasolines were sold at the same price, wouldn't you?"

"A. Oh, I would be delighted, yes, sir." Record at 2,114.

${ }^{38}$ Edwards, Maintaining Competition 167 , 168 (1949).

${ }^{39}$ Brief for Petitioner at $32-34,56,57$, Standard Oil Co. v. Federal Trade Commission, 340

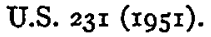

$4^{\circ} 49$ Stat. $5_{5} 26$ (I936), I5 U.S.C.A. § I3(b) (I95I).

4I Ibid. 
The trial examiner found that Standard's recognition of the four buyers as jobbers was in conformity with industry practice and that the lower prices given them were granted in good faith to meet equally low prices of competitors. Pertinent evidence indicated that the jobbers had received several offers from competing suppliers, offers which were equivalent to or below Standard's tank car price.

The Commission refused to make a finding on this question, holding that the Section 2(b) proviso did not set out an absolute defense in the face of affirmative proof that the discrimination resulted in an injury to competition. Following the language of the circuit court decision, ${ }^{42}$ the Commission intimated in the Supreme Court that the defense might have greater weight in a case where there was no injury to competition among competing purchasers. ${ }^{43}$ In this view, the dictum in Moss v. Federal Trade Commission 44 would be limited to its facts (purchasers among whom seller discriminated were not in competition with each other; only injury to competition was on the seller level) and the Glucose cases $^{45}$ would become precedents for denying the defense where injury was to second or third line competition. ${ }^{6}{ }^{6}$ Justice Burton, speaking for five members of the Court, held, however, that the Section 2(b) proviso did set out an absolute defense. In so doing, he relied on ( $\mathrm{r}$ ) the relation between the Robinson-Patman Act and Section 2 of the Clayton Act 47 which it amended, (2) dicta from prior cases and (3) what he described as a "widespread understanding" that the defense was complete. To the majority, the troublesome legislative history was, at best, inconclusive. Noting the argument that the Robinson-Patman Act is inconsistent with the antitrust philosophy of the Sherman Act, the Court felt that, "[i]t is enough to say that Congress did not seek by the Robinson-Patman Act either to abolish competition or so radically

42 "The discrimination in price in favor of the parties in this case, which the petitioner had a righi to make as against its competitors, was then used by the petitioner's customers to work havoc among competitors on the retail level." Standard Oil Co. v. Federal Trade Commission, 173 F. 2d 210, 216 (C.A. 7 th, I949) (emphasis added).

43 Brief for the Federal Trade Commission at 37, Standard Oil Co. v. Federal Trade Commission, 340 U.S. 23I (I95I); Transcript of oral re-argument at 83, 84 (Oct. 9, I950).

44 r48 F. 2 d 378 (C.A. 2d, 1945), cert. denied 326 U.S. 734 (I945) clarified I55 F. 2d Ior6 (C.A. 2d, I946); Shniderman, "The Tyranny of Labels"-A Study of Functional Discounts Under the Robinson-Patman Act, 60 Harv. L. Rev. 571, 595 n. 87 (I947).

${ }^{45}$ Corn Products Refining Co. v. Federal Trade Commission, 324 U.S. 726 (1945); Federal Trade Commission v. Staley Mfg. Co., 324 U.S. 746 (I945). In these two companion cases, the injury to competition was among purchasers. Sellers of glucose were held to have discriminated among their customers by maintaining a single basing point delivered price system. The purchasers were candy manufacturers whose distance from a favored price zone created by the basing point system accounted for marked competitive advantages and disadvantages.

${ }^{6}$ Neither the words of the statute nor the legislative history afford support for the FTC's position which was, apparently, that an injury to second and third line competition is somehow worse than an injury to competition on the seller level. The importance of price discrimination as a device by which sellers may "break away" from price agreements suggests that if the competition defense is to have effect anywhere it should have it vis-à-vis first line competition. Edwards, op. cit. supra note 38 .

${ }_{17} 3^{8}$ Stat. 730 (I9I4). 
to curtail it that a seller would have no substantial right of self-defense against a price raid by a competitor." $4^{8}$

Section 2 of the original Clayton Act expressly excepted from its coverage, "discrimination in price in the same or different communities made in good faith to meet competition." 49 The Robinson-Patman Act amended that section in several respects here relevant. It was divided into subsections, Section 2(a) retaining the statement of the substantive offense and a series of provisos "justifying" otherwise unlawful price discrimination. Section 2 (b) places the burden of proof on a seller who would show justification for proven discrimination and continues with the "competition" proviso.

Justice Burton reasoned that the amendment narrowed but did not "cut into the core of the defense." The dissenting justices emphasized the congressional purpose to close loopholes in the Clayton Act section and urged that the majority position nullified the effect of the amendatory statute in this respect. Justice Reed, dissenting, read all of Section 2(b) as procedural and relied on legislative history in concluding that the "good faith meeting of a competitor's price only rebuts the prima facie case of violation established by showing the price discrimination. Whether the proven price discrimination is of a character that violates Section 2(a) then becomes a matter for the determination of the Commission on a showing that there may be injury to competition."so

Standard had charged that the Commission's construction of Section 2(b) would in effect strip the proviso of all meaning. ${ }^{5}$ The Court agreed that, so interpreted, it would become practically meaningless. The FTC ${ }^{2}$ and the dissenting judges took the position that recognizing the defense as absolute would in effect re-enact the loophole in Section 2 of the original Clayton Act. In view of the familiar criticisms of the Robinson-Patman Act as an "anti-competition" statute and the sharpness of the disagreement about Section 2(b), it becomes important to consider the scope of the "competition" defense. For its treatment may well determine the fate of the statute itself as well as the finding which the Commission must now make in the Standard case.

In the Supreme Court opinion, the word "lawful" is engrafted onto the statù-

${ }^{48}$ Standard Oil Co. v. Federal Trade Commission, 340 U.S. 23r, 249 (r95r).

${ }^{49} 3^{8}$ Stat. 730 (I9r4).

${ }^{50}$ Standard Oil Co. v. Federal Trade Commission, 340 U.S. 23I, 267 (195x).

5x Tbid., Brief for Petitioner at 2I, 36. The argument is that if the defense is unavailable where there is affirmative proof of injury to competition, then it will be unavailable in every case, following the holding in Federal Trade Commission v. Morton Salt Co., 334 U.S. 37 (I948) (FTC need only find a reasonable possibility of injury to competition in order to prohibit price discrimination; a showing that price differentials between competing purchasers are large enough to influence resale prices will support a finding of the "statutory" injury to competition). That the broad construction of the Morton Salt case may be "under a cloud," see Minneapolis-Honeywell Regulator Co. v. Federal Trade Commission (C.A. $7^{\text {th, July 5, }}$ I95I) and Ruberoid Co. v. Federal Trade Commission (C.A. 2d, June 4, I95I).

32 Brief for the Federal Trade Commission at $\mathrm{I} 7$, Standard Oil Co. v. Federal Trade Commission, 340 U.S. 23 I (I95 I). 
tory "equally low price of a competitor" several times. This appears to follow the language of Federal Trade Commission v. Staley Mfg. Co.53 in which Chief Justice Stone characterized as "startling" the contention that a seller could justify an otherwise unlawful basing point delivered price system because competitors were in part violating the law by maintaining like systems. ${ }^{54}$ There is support in the legislative history for thus reading the statute. 55 However, it is not clear whether a seller relying on this defense must show affirmatively that the competitor's price which he sought to meet was in fact a lawful price. Since the legality of such prices may require administrative and judicial determination, such a burden of proof might well be unjustifiably onerous..$^{6}$ -

In the Staley case, the Court further read Section $2(\mathrm{~b})$ as placing emphasis on individual competitive situations rather than on a general system of competition. Thus, a seller may be unable to rely on the defense where he has followed a competitor's price system. ${ }^{57}$ Such price policy is open to attack not only as being beyond the purview of the singular "equally low price of a competitor" but also under the good faith requirement as regards the seller's intent. Just what is an "individual competitive situation" is not revealed by the cases. How far must a seller move from the one extreme of adopting a competitor's discriminatory price system in order to come under the Section 2(b) proviso? The safest course would be to isolate each transaction or, at least, each customer, for price-setting purposes. Where meeting competition results in price differentials as among different customers in the same community, this may be the only safe course. ${ }^{58}$

The scope of the good faith requirement itself raises many problems. In the Staley case, the evidence showed little diligence on the part of the seller to verify reports of competitive prices which he received from salesmen, brokers and prospective buyers. The Court prescribed a general answer, to the effect that the statute at least requires a seller to "show the existence of facts which would lead a reasonable and prudent person to believe that the granting of a lower price would in fact meet the equally low price of a competitor." least two difficulties. The Staley court was concerned only with the first, the danger of making the seller's burden of proof too difficult. On the other hand, if sellers are to be encouraged to verify competitive prices, the Sherman Act might provide trouble. With reference to the conspiracy problem, courts would be wise to neutralize the possible invitation which Section $2(b)$ thus sets up to

53324 U.S. 746,753 (I945).

54 Ibid., at 753 .

5580 Cong. Rec. 9,4 I8 (June 15, I936).

${ }^{6}$ Berger and Goldstein, Meeting Competition under the Robinson-Patman Act, 44 Ill. L. Rev. 315, 323 n. 4r (r949).

57 See Federal Trade Commission v. Cement Institute, 333 U.S. 683, 725 (I948).

${ }^{8}$ In contrast to the basing point situation.

s9 Federal Trade Commission v. Staley Mfg. Co., 324 U.S. 746, 759, 760 (I945). 
the maintenance of open price systems, or at least some kind of price communication among sellers. ${ }^{60}$

It is clear that a seller must not intentionally undercut his competitor's price where the requisite effect on competition follows. But must he show that he did not undercut them? Closely related is a question which the Court of Appeals for the Second Circuit left open in Moss. v. Federal Trade Commission, ${ }^{6 \mathrm{r}}$ whether "good faith" means merely intent to sell at the price named or intent to approach a competitive price. ${ }^{62} \mathrm{On}$ the answer to that question may depend the consequences of accidentally undercutting a competitor's price.

A more serious problem is raised by the language of the Standard case itself. A seller is allowed to match competitive prices as a defensive measure, i.e., to retain going customers as against aggressive competitors. But may he do more than simply protect his established buyer accounts? If he tries to obtain new customers, he is unable to undercut the lowest competitive offer made to them, which means that in most cases he will have no price differential to offer as an inducement.

Questions such as the last indicate how future treatment of the competition defense can affect the scope of the whole statute. If, for example, competitive price discrimination is allowed only as a defensive measure, the effect of the statute will be to freeze further existing market distributions and prohibit price competition where it is often most sorely needed. Thus, it is necessary to return to the FTC's problem in evaluating Standard's contention that its lower jobber prices were justified under the competition proviso of Section 2(b).

In the Supreme Court, the Commission pointed out that had it made a finding of fact on the good faith issue, it could well have made a "vigorous" interpretation of the statutory language. ${ }^{63}$ Indeed, there are several ways in which the Commission may rule against Standard. Following the Staley case, it may be argued that Standard's jobber differential was set on a customer classification basis rather than granted in "individual competitive situations." Thus, Standard's failure to lower its jobber prices to meet lower competitive offers might itself be treated as evidence of a lack of good faith. Further, there is no showing that the competitive offers on which Standard relies were themselves lawful prices. ${ }^{6}{ }_{4}$ Much of the evidence is open to the construction that Standard granted the price differential to jobber customers and then sought to justify it on the basis of subsequent competitive offers. If so, the requisite intent may be found lacking.

The scope of the competition defense under Section 2(b) of the Robinson-

${ }^{60}$ See Trade Association Statistics and the Anti-Trust Laws, I8 Univ. Chi. L. Rev. 380 (I95I).

${ }_{6 x}$ I48 F. 2 d 378, 380 (C.A. 2 d, x945); clarified I $_{55}$ F. 2 d Ior6 (I946).

62 Ibid., at 380 .

${ }_{63}$ Brief for the Federal Trade Commission at 44,45 , Standard Oil Co. v. Federal Trade Commission, 340 U.S. 23 I (I95I).

${ }^{6}$ See text at pp. $66-67$ supra. 
Patman Act is, then, highly uncertain. Perhaps the limit of present knowledge is that there must be good intentions under the proper circumstances.

\section{IV}

Commentators have almost unanimously condemned the FTC's position in the Standard case..$^{65}$ Apart from questions of statutory construction, the main ground of criticism has been that to so limit the effect of a showing that lower prices were granted to meet competition would defeat the supposed purpose of the statute to encourage competition. More immediately compelling, however, is the specific conclusion suggested by analysis of the Detroit market. The price discrimination benefited consumers by promoting price competition on a retail level and by driving a chink in the wall of price uniformity maintained by the major suppliers who dominated the market. Perhaps Detroit was then a peculiar market because of the accessibility of Michigan crude production and surplus stocks which seemed to free independent marketers from the major company domination alleged to exist elsewhere in the industry. If so, this adds to the force of the conclusion that Standard's price discrimination was both a symptom of and an aid to competition.

But the critics go beyond the Standard case and insist that the basic philosophy of the Robinson-Patman Act is opposed to that of earlier antitrust legislation. ${ }^{66}$ The general interdiction of price discrimination indeed does have the effect of freezing price levels and hampering sellers who would break way from monopolistic arrangements. ${ }^{67}$ Added to this is the fact that the statute itself calls for the identification of injury to "competition" with injury to "competitors." 68 The latter is, after all, supposed to be one of the normal consequences of vigorous competition. And when, as here, forbidding price discrimination takes the form of promoting resale price maintenance, it is clear that the Sherman Act is receiving little more than lip service. ${ }^{69}$

65 Adelman, Integration and Antitrust Policy, 63 Harv. L. Rev. 27, 60 ff. (I949); Austern, Required Competitive Injury and Permitted Meeting of Competition, New York State Bar Ass'n, Robinson-Patman Act Symposium 63 (CCH, 1947); Berger and Goldstein, op. cit. supra note 56 ; comments cited note 8 supra.

${ }^{66}$ See, e.g., Burns, The Anti-Trust Laws and the Regulation of Price Competition, 4 Law and Contemp. Prob. 301 (1937); McNair, Marketing Functions and Cost and the RobinsonPatman Act, 4 Law and Contemp. Prob. 334 (I937); Learned and Isaacs, The Robinson-Patman Law: Some Assumptions and Expectations, I5 Harv. Bus. Rev. 137 (1937); authorities cited note 65 supra.

${ }_{7}^{6}$ Edwards, Maintaining Competition I59-7x (1949).

${ }^{68}$ Simon, The Fantasy of the Phrase "Injury to Competition," I5 Law and Contemp. Prob. $25^{8}$ (1950).

69 See Resale Price Maintenance and the Anti-Trust Laws, 18 Univ. Chi. L. Rev. ${ }^{669}$ (195I); The Swinging Door-Or How To Obey One Antitrust Law by Violating Another, 59 Yale L.J. ${ }^{8} 8$ (1949). According to the original cease and desist order, jobbers qua retailers would receive no differential under tank wagon price. Jobbers qua wholesalers could be given such a differential but only if they did not pass on part of it by reselling to dealers at less than Standard's tank wagon price. Treating the jobbers qua retailers, a proviso allowed differentials of less than $\frac{1}{2} \&$ a gallon which did not injure competition. Neither the source nor the purpose 
The injury to competition which the FTC found in Detroit consisted of injury to the small retail dealers who were caught in a squeeze between uniform "sticky" tank wagon prices and vigorous price cutting by competing retailers. They had the choice of cutting prices to maintain their sales (on greatly reduced margins) or maintaining prices and losing substantial gallonage. $7^{\circ}$ Although they were not openly "tied" as were the dealers in Standard Oil Co. (Calif.) v. United States, ${ }^{72}$ as a practical matter the dealers buying from major suppliers were not free to sever their connections and seek lower tank wagon prices elsewhere. ${ }^{22}$ In the circuit court decision, (then) Judge Minton noted the argument

of the $\frac{1}{2} \&$ figure is revealed. Ostensibly, it was a recognition of the fact that there was some cost saving involved in sales to jobbers who maintained their own bulk plants as compared with sales to individual dealers. The difficulty connected with the FTC's treatment of the attempted cost justification is dealt with elsewhere. Adelman, op. cit. supra note 65 at $64-66$. However, the $\frac{1}{2} \&$ leeway is a strange recognition of cost justification if such itwas intended to be, since it was conditioned on a lack of injury to competition in the original order. This runs counter to the terms of $\S 2$ (a) which sets out cost justification as a complete defense. Nor has the Commission ever questioned the absolute character of this defense. Following a motion by Commission counsel to modify the original order, the final order dropped mention of the $\frac{1}{2} \xi$ figure and added a general proviso sanctioning price differentials which made only due allowance for cost savings.

Commissioner Mason, dissenting, objected to what he termed "determining price by use" involved in the order insofar as it required different prices to be given the jobbers on gasoline sold at retail from that which they sold at wholesale. However, in this respect the order broke no new ground. Urbana Laboratories, 26 F.T.C. 3I2 (I938); Nitragin Co., 26 F.T.C. 320 (1938); Hansen Inoculator Co., 26 F.T.C. 303 ( $(938)$; Shniderman, op. cit. supra note 44 at 592 ff. The difficulty which Commissioner Mason saw in this aspect of the case stemmed from the fact that both retail and wholesale functions were combined in the jobbers' operations. However, the dual pattern of the supplier, in selling both to dealers at a posted tank wagon price and jobbers at a lower tank car price, was the source of trouble concerning paragraph 6 of the modified order. This paragraph required Standard to grant no price differential to jobbers qua wholesalers where in selling to dealers they undersold Standard's tank wagon price. Standard attacked this as requiring resale price maintenance, a curious result, if true, in view of the Commission's long standing opposition to resale price maintenance. In the circuit court, this paragraph was challenged further as unreasonably requiring Standard to police its jobbers' resale price policies. The court amended the paragraph so as to lighten this burden, holding that Standard should be liable only if it sells to a wholesaler whom it knows or ought to know is passing on part of his tank car differential to dealer customers. The attempt to make this look like something other than a price control arrangement violating the Sherman Act was not attended with much success. Adelman, op. cit. supra note 65 at $73 ; 59$ Yale L. J. I 58 (1949). The dissenting opinion in the Supreme Court suggested that were the order affirmed, some change might have to be made in its wording, probably adverting to paragraph 6 which had been the subject of much disagreement on oral argument. Counsel for the Commission in fact expressed "personal doubts" about this aspect of the order. Transcript of oral re-argument at 84, 85, 94 (Oct. 9, I950), Standard Oil Co. v. Federal Trade Commission, 340 U.S. 23 I (I95 X).

${ }^{70}$ Actually, the dealers would have been at a similar competitive disadvantage even if the jobbers had not passed on any of the price differential by cutting retail prices, since the latter could have used their larger profit margin for expansion, advertising, etc. Cf. Record at 224, 332. On the other hand, jobbers would suffer a theoretical discrimination if forced to pay dealer tank wagon prices while they were reducing seller costs. Adelman, op. cit. supra note 65 , at 63 . However, it is settled that the statute does not extend to the latter type of discrimination. Edwards, Maintaining Competition x64, I65 n. 9 (I949).

${ }^{7 x} 337$ U.S. 293 (I949).

72 In his dissent, Commissioner Mason insisted that there was no injury to competition in Detroit since, "at no time were there any competitors shut out from buying gasoline of like 
that enforcement of the FTC cease and desist order would have the effect of driving jobbers out of business. He replied, "If this be true, it is elimination only where their existence cannot be justified except on the exploitation of a differential in price not justified by any cost savings to obtain that price. This does not impress us as either illegal, unwarranted, or unjust." ${ }^{73}$ The argument could be extended and paraphrased to apply to individual retail merchants who are at a competitive disadvantage in situations where price competition is keen. The basic objection to such a paraphrase stems from the policy of the RobinsonPatman Act itself. In essence, it is that small businessmen should somehow be protected from the rigors of competition with the efficiency and bargaining power of large rival concerns. ${ }^{74}$ If the statute is thus styled an indirect subsidy to small business, it seems that, in principle, a direct subsidy to small business would be more desirable. Such an approach would at least not have the disadvantage of discouraging competition on all levels of trade.75

grade and quality at prices ranging from 2 to 6 cents less than they were paying, and at a price always less than the respondent's so-called discriminatory price." Standard Oil Co., 43 F.T.C. 56, 68 (1946). The Commission's holding, according to Commissioner Mason, in effect engrafted the notion of like "brand name" or "public acceptance" onto the statutory "like grade and quality." It is true that the jobbers, who had no term agreement with their suppliers, were theoretically free to change suppliers at any time. But the dealers, suffering from the alleged injury to competition, were in a different situation. Two hundred and eight of Standard's three hundred and fifty-eight dealer customers either leased or subleased from Standard the filling stations which they operated. The leases were for one-year terms, renewable for either six months or one year upon expiration. Commission's Exhibit No. I-A, Record at 4,702. Although these lessees had no agreement binding them to sell only Standard products, none of these stations, understandably, were ever serviced by any company other than Standard. Record at 2,902. Nor was it Standard's "policy" to lease its stations to anyone except an operator who was to purchase his gasoline from Standard. Record at 2,r24. The remaining one hundred and fifty dealers owned their stations and had contracts binding them to buy their requirements of Standard's products from Standard. The leases ran for one year and sometimes for longer periods. Commission's Exhibit No. 2, Record at 4,7 I3. Equipment loans were conditioned on the dealer's dispensing only Standard products from such equipment. Commission's Exhibit No. 8o, Record at 4,766. The need to be assured of adequate supplies and established good will attached to the sale of one supplier's products were further factors restricting these dealers' practical freedom of movement as regards changing suppliers.

Another circumstance reminiscent of the I 949 Standard of California case is the warning made by Standard in the Supreme Court that if they should be forced to forego selling on a dual basis in Detroit, they might have to take over the businesses of the jobbers whom they could no longer serve. Brief for Petitioner at 57 , Standard Oil Co. v. Federal Trade Commission, 340 U.S. 23I (r95I). Cf. Justice Douglas' dissent in Standard Oil Co. v. United States, 337 U.S. 293, 32I (r949).

${ }_{73}$ Standard Oil Co. v. Federal Trade Commission, I73 F. 2d 210, 217 (C.A. 7 th, I949).

74 Burns, op. cit. supra note 66 at $308 \mathrm{ff}$. Cf. Justice Black's statement that "in enacting the Robinson-Patman Act, Congress was especially concerned with protecting small businesses which were unable to buy in quantities. ..." Federal Trade Commission v. Morton Salt Co., 334 U.S. 37, 49 (r948). In vetoing Sen. I008, President Truman expressed the fear that it might impair the effectiveness of the antitrust laws and twice referred to the Robinson-Patman Act as a protection against "ruthless price cutting." 96 Cong. Rec. 8,844 (June I6, I950). Compare Congressman Patman's review, a few days later, of ten years under the RobinsonPatman Act, 96 Cong. Rec. 8,9II (June I9, I950).

75 But cf. Adelman, op. cit. supra note 65 at 77 n. I53: "It would take a skilled intellectual contortionist to consider the Indiana Siandard case as involving small v. big business.". 
The attempt of the Detroit gasoline dealers to freeze retail prices is understandable as a defensive measure calculated to preserve profit margins. Styled differently, they did not want to bear part of the cost of meeting independent competition in order to protect the major suppliers' share of the market. The problem is really set by the fact that there was no price competition to speak of among the major suppliers as far as tank wagon prices were concerned. And the practical remedy lies in the direction of attacking whatever monopolistic arrangements there are behind the action of the major suppliers. This is emphasized by the circumstances of the Standard case. The complaint and the evidence are now eleven years old. An intervening war and six strange years of peace have wrought many changes. There appears to have been no general price war in Detroit since the year in which the FTC complaint was filed. Since that time, Michigan crude production has dropped significantly..$^{76}$ And the number of independent refineries in the state has dropped as the problem of petroleum shortage has come to overshadow memories of the depressed market of the middle thirties. In these circumstances, the situation needs fresh investigation. It is doubtful that the Robinson-Patman Act is the proper instrument for such investigation.

Detroit is only one market. Perhaps its peculiarities between I $_{93} 6$ and I940 outweigh the characteristics which it then had in common with markets elsewhere in the industry. The changes of the past eleven years suggest the opposite conclusion. To the extent that such price discrimination is a symptom of industry-wide problems, the difficulties encountered in Detroit emphasize the need for a decision on the broad charges against the major oil companies. Bringing the Mother Hubbard type of case to trial would certainly be a step in this direction, probably an inadequate one if the claim for relief is not expanded and presently an improbable one as the pace of mobilization is accelerated. ${ }^{77}$ In view of the fact that price discrimination is often the most potent "natural" force tending to undermine monopolistic arrangements, the dropping of the Mother Hubbard case itself adds emphasis to the desirability of price discrimination in gasoline marketing.

The problems of Detroit illustrate the pressures felt by courts and administrative agencies in dealing with conflicting legislative policies. It is easy to say that the determination of such conflicts is for the legislature. However, the end is difficult to reach where, as here, the conflict is based on a deeply-rooted inconsistency in sentiments about desirable forms of commercial behavior.

to U.S. Dept. of Commerce, Statistical Abstract of the United States 7ro (r950); Nat'l Industrial Conference Board, Petroleum Almanac 37 (I946).

77 The Justice Department has now dropped the Mother Hubbard case in favor of individual actions involving fewer defendants and more limited issues. Wall Street Journal, p. 8, col. 2 (June 7, I95 I). 